\title{
Analysis on the Causes of the Plight of Chinese Rural Migrant Workers' Endowment Insurance
}

\author{
Huofa Luo
}

\begin{abstract}
At present, Chinese society is from traditional society to modern society in transition to accelerate, in the social, political, and economic structure, great changes have taken place; due to strong liquidity, migrant workers' groups in social security, are still in the stage of development, and there are still a lot of problems, especially the problem of endowment insurance. Although local governments develop the old-age insurance of migrant workers with their own characteristics, and have their respective advantages, but the effect is not ideal, as follows: "one low and one high", namely the migrant workers' participation rate was low and the insurance of migrant workers was "high rate of surrender". The reason is both within the Chinese social transformation factors, and external economic globalization competition; both objectively, government policy implementation is not in place, and subjectively, migrant workers lack insured willing.
\end{abstract}

\section{Keywords}

Transition period, rural migrant workers, endowment insurance, dilemma, causes

At present, Chinese society is from traditional society to modern society in transition to accelerate, in the social, political, and economic structure, great changes have taken place. Some areas although cancelled the division of agricultural and non-agricultural household, but are affected by the "urban-rural dual structure" inertia. Due to strong liquidity, migrant workers' groups in the social security, did not enjoy the same rights as urban residents. This is a direct factor leading to the dilemma of endowment insurance of migrant workers. As China's current social security objects, they are mainly urban residents, migrant workers on the whole are in a low level of security, and even no guarantee. The social security of migrant workers is still in the stage of development, there are many problems, the most prominent problem is in the old-age insurance. Although local governments develop the old-age insurance of migrant workers with their own characteristics, and have their respective advantages, but the implementation effect is not ideal for: "one low and one high", namely the migrant workers' participation rate was low and the insurance of migrant workers was "high rate of surrender" (Chen 2012).

Although the state of migrant workers to participate in pension insurance has been made, but there has not yet formed the effect of enforcement. Some local governments combined with local conditions, to advance the development of the actual migrant workers endowment insurance policies and regulations for the local migrant workers to enjoy the treatment of old-age insurance. Mao (2013) explained some achievements have been achieved, from the

ajiaxing University, Jiaxing, Zhejiang, China

\section{Correspondent Author:}

Huofa Luo, 56 Yuexiu South Road, Nanhu District, Jiaxing City, Zhejiang Province, China, zip code: 314000 
whole point of view, the policy of migrant workers pension insurance system in all parts of the country has not formed an unification, and there is no uniform laws and regulations guide (Mao 2013). Although the policy of the central government to local policy is guided by the constraint role, but in some places in the implementation of the central policy, joined the local regulations at the same time, thus formed the different migrant workers endowment insurance policies and regulations in the different place.

\section{A SURVEY OF THE PLIGHT OF MIGRANT WORKERS' ENDOWMENT INSURANCE}

Because China's current endowment insurance system for migrant workers lacks standard and unification, the area according to the characteristics of migrant workers, develops distinctive peasant workers' endowment insurance policy, but these policies not only make endowment insurance for peasant workers' salary difference larger (see Table 1), but also make their pension insurance relationship difficult to continue.

Migrant workers' pension insurance system design is missing, and is a lack of policy drive. China's old-age insurance system began in the early 1950's. Since the reform and opening up to the beginning of this century, with the growing number of Chinese workers and staff and the number of retirees, the state has issued a number of worker endowment insurance policy documents, but the old-age insurance, does not take the migrant workers into account as a special group. In recent years, some places though create some new old-age insurance of migrant workers experience, but these practices, to the household registration as a dependency of the migrant workers for premise, with strong local economic base for support, the liquidity of old-age insurance for rural migrant workers issues, explore the feasible plan yet. Leading to remote connection is very troublesome, cannot satisfy the needs of migrant workers, resulting in ginseng enthusiasm is not high. At present, the rural migrant workers' endowment insurance system is not perfect, which restricts the development of the endowment insurance of rural migrant workers, which is outside the coverage of the social pension insurance system design.

Migrant workers' pension insurance contribution base and ratio of diversified insurance relationship transfer to cross. Due to the different regional economic development level, the diversification of the base and the ratio of fee, to ensure social equity objectives is necessary. Zhang (2013) argued that the characteristics of migrant workers mobility are not only reflected in the urban and rural areas, but also in the performance of the occupation and the unit (Zhang 2013). At this stage, China's pension fund has not yet achieved the national co-ordination point, there is a sharp contradiction. In real life, migrant workers often change jobs, there is often no way to transfer, and to maintain the relationship between endowment insurances. The result is: Migrant workers cannot enjoy the social pension insurance of Pratt \& Whitney.

Government is in the absence of the implementation of pension insurance for migrant workers, the company avoids the corresponding responsibility. Urban and rural dualistic system, is easy to cause the government to protect the rights and interests of migrant workers in the implementation of the "absence" and "dislocation" phenomenon. Many management departments, in the protection of the rights of migrant workers, there exists tendency of the main city, migrant workers are only regarded as labour, rather than in a city as a member of a society; in order to attract foreign investment, many cities turn a blind eye to whether the enterprise provides insurance, some local governments even make preferential conditions without buying migrant workers insurance to attract foreign capital. These governments have only seen their economic interests, and have not seen the relationship between enterprise development and local economic development. It is 
Table 1. Three Types of Endowment Insurance Policy Differences

\begin{tabular}{|l|l|l|l|}
\hline Project & Type & Independent type & Inclusion type \\
\hline Financing model & $\begin{array}{l}\text { Personal account and social } \\
\text { pooling1 }\end{array}$ & Old age allowance & $\begin{array}{l}\text { Personal account and social } \\
\text { pooling }\end{array}$ \\
\hline $\begin{array}{l}\text { Docking with the urban } \\
\text { system }\end{array}$ & Very difficult & Cannot & $\begin{array}{l}\text { Can be implemented in the } \\
\text { local docking }\end{array}$ \\
\hline Account transfer connection & Can be transferred in the city & Cannot & $\begin{array}{l}\text { Conditional transfer } \\
\text { connection }\end{array}$ \\
\hline Surrender way & $\begin{array}{l}\text { Can only be returned to the } \\
\text { individual account, cannot be } \\
\text { drawn as a whole account }\end{array}$ & $\begin{array}{l}\text { Not to surrender in advance, } \\
60 \text { year old male, female } 50 \\
\text { years old to the insurance } \\
\text { company redeemed }\end{array}$ & $\begin{array}{l}\text { Provisions to the retirement } \\
\text { age and not enough time to } \\
\text { pay a certain percentage of } \\
\text { one-time living expenses }\end{array}$ \\
\hline
\end{tabular}

estimated that the enterprises to participate in social insurance, will increase their total operating costs about 2\%-3\%. Local farmers to participate in pension insurance, although some institutional provisions have been made, the premium payment rate is too high, which is a direct impact on the enthusiasm of enterprises. And because the supervision and control mechanism is not in place, enterprises try to escape the responsibility to pay for the pension insurance.

\section{CAUSES OF THE PLIGHT OF RURAL MIGRANT WORKERS' ENDOWMENT INSURANCE}

From the plight of the pension situation of migrant workers, China still exists the phenomenon that enterprises and migrant workers are not willing to participate in the insurance, the insured rate is low. The system is not unified; gap is big; the insured rate is low; the rates of surrender are high, these are indisputable fact situation of endowment insurance of rural migrant workers at present. Migrant workers' pension insurance coverage rate is about $15 \%$, while the average lapse rate reaches $40 \%$, mainly due to migrant workers' lack of trust on the endowment insurance system, local governments are reluctant to increase spending, companies are reluctant to pay for migrant workers. Specific is as follows:

\section{The Old-Age Insurance Policy of Migrant Workers Is Not Reasonable, and the Management Method Is Backward}

Within the rural migrant workers' pension insurance system in China, the relationship between the endowment insurances of migrant workers is transferred and continued, there are two unreasonable points:

First, the relevant provisions of the State Council in 1997 promulgated clearly defined, everywhere to participate in the work of employees, if its pay endowment insurance gold years reach a total of more than 15 years, after the worker is retired, he can get monthly payment of basic pension; if payment of pension insurance is in limit under 15 years, after the worker is retired, personal savings account is a lump sum payment;

Second, issued by the Ministry of Labor in 2001 on issues concerning the improvement of the policy of basic old-age insurance for urban workers notice expressly stipulated, if the enterprises and employees terminate or abolish the labor relations, workers can only be removed from endowment insurance fund account individual pay part to enjoy part of the overall interests of society. Generally speaking, after termination of the labor relationship, workers can only be removed in the account to pay part of the individual funds, as well as the payment period of 15 years of 
strict rules, making those with greater mobility and lower income of migrant workers pension insurance relationship transfer difficult, resulting in the policy difficult to implement.

\section{The Implementation Failure of the}

\section{Endowment Insurance Policy for Peasant} Workers

The endowment insurance policy of migrant workers involves many benefits distribution and adjustment, the widespread policy implementation is a failure, weakening the authority of the government, damaging the benefit of the policy. In the current social security work of migrant workers, the reason lies in the failure of the implementation of its policy implementation:

First, there is the existence of the "lemon market" effect. Degree of information publicity in public policy, public policy implementation effect, due to the single mode of transmission of public policy, resulting in weak public awareness of government information and open system, coupled with the relative lack of the protection of the rights and interests of migrant workers, and the farmers and the government in the policy identity information asymmetry. This single, vertical channel for the dissemination of information, is difficult to meet the migrant workers on the policy informed need, results are that many migrant workers choose not to be insured and surrender, this "surrender expel the insured" phenomenon, resulting in social security of migrant workers market malaise;

Second, the allocation of resources to the implementation of the policy is not fair. Resource policies, security policies for the effective implementation of various conditions, usually include human resources, financial and material resources, information resources and authoritative resources, and credit resources. Therefore, the government is responsible for the public, including migrant workers, to provide a fair and equal stage, rather than a magnetic field of interest;
Third, there is the lack of interest in the interests of migrant workers' "spokesman". The position of migrant workers is weak, in the political, organizational, and social level, according to statistics, only $13.2 \%$ of migrant workers participated in the trade union organization, $12.6 \%$ had been helped by the trade unions. Because there is a lack of spokesmen for the interests, interests of the migrant workers still cannot make strong political needs, in the distribution of benefits under the background of diversification of interests orientation and redistribution, the migrant workers is exploited. This is "labor, non-continuity, income instability” for the professional characteristics of migrant workers, which is too harsh.

\section{Migrant Workers' Lack of Appropriate Understanding of the Old-Age Insurance System, Weak Awareness of the Insured}

Asymmetric information between migrant workers and the national government, is very easy to cause the development of the system, and migrant workers on the system level of cognition between the faults, resulting in the actual implementation of the difficulties. From the system level, it has formed the endowment insurance system for migrant workers, mostly from the macro level, considering that migrant workers have their own characteristics.

From the point of view of migrant workers, migrant workers' thought is very simple, as long as they finish the work and can successfully get their wages, they are very satisfied, with little regard for inductrial injury insurance, medical insurance, etc. They ignore a series of the enjoyment of social security rights, especially pension for them. At the same time, the cultural level of migrant workers is generally low, belonging to the social low income class, even if it is a low income, there is still a huge instability. Therefore, for migrant workers, they tend to pay more attention to real income.

On the other hand, receiving the ingrained traditional ideological influence, they tend to get 
pension sustenance from children and rely on the land of the family endowment insurance, especially in recent years, the government not only cancels the agricultural tax but also increases the land subsidies. Between the long-term and short-term interests, plus a series of uncertain factors, migrant workers tend to choose the immediate visible benefits, due to the expectation and the reality of social security of the game, so that they chose to give up the endowment insurance.

\section{The Contradiction Between the Particularity of Migrant Workers and the Existing Old-Age Insurance System}

Because the endowment insurance of migrant workers' insured rate is low, the reason of high refund rate is in many aspects, from the theoretical level, in the current endowment insurance system, between the particularity of migrant workers groups and endowment insurance system, there are some contradictions.

The contradiction is between the low income of migrant workers and the high rate of endowment insurance. Migrant workers' income is low and unstable. Migrant workers, mostly engaged in heavy, tired, dirty, and dangerous work, whose income is generally lower than the average wage of the public. According to a sample survey made in Hunan, Sichuan, and Henan provinces, the rural migrant workers' monthly actual working time is more than $50 \%$ of the staff members and workers in cities and towns, but the average monthly income is less than $60 \%$ of the average wage of staff and workers in cities and towns, actual labor hourly wage is only $1 / 4$ of urban workers. Most migrant workers shoulder the family burden, and the old and the small, in addition to the basic life need, also pay for their children's education, elderly support, if let them take out the salary of $4 \%-8 \%$ to pay which is not that they are most in need of the endowment insurance, they will resist emotionally.

The contradiction is between the mobility of migrant workers and the payment period of endowment insurance. Liquidity is strong, is an important feature of migrant workers, and in the short term, this feature will not disappear. Migrant workers in the city, are mainly engaged in the catering industry, manufacturing industry, construction industry, service industry, but migrant workers in the catering industry, factories, and enterprises, the average workers period is 3-5 years, engaged in the construction of pure physical work of migrant workers, in a place to work, the average workers period is 2-3 years, they often are not up to 15 years, the lowest capture expends fixed number of year, and thus causes the formation of "insured, surrender to be insured, and surrender" vicious circle.

\section{CONCLUSIONS}

Due to more migrant workers to retire at the local, local fiscal pension needs to cost more. Therefore, out of the surrender of migrant workers, the essence is to help the local government to reduce the burden of pension payment in the future. Also due to the payment of pensions, consisting of three parts-the government, units, and individuals, and surrender in advance can only retrieve individual pay, i.e. unit needs to pay most of the costs, which directly discharges into the local social security fund can also be buffer to raise fund spending pressure. Thus, local social security institutions are keen to expand social security on one hand, and actively apply for refund procedures on the other hand, which is the strange phenomenon. Although local governments develop the old-age insurance of migrant workers with their own characteristics, and have their respective advantages, but the effect is not ideal, as follows: "one low and one high”, namely the migrant workers' participation rate was low and the insurance of migrant workers was "high rate of surrender". The reason is both within the Chinese social transformation factors, and external economic 
globalization competition; objectively, government policy implementation is not in place, but also subjectively, migrant workers lack insured willing.

\section{Notes}

1. The so-called "overall" is within a certain range, unified planning of endowment insurance fund collection, management, and use, each district coordinating is responsible for the region of the endowment insurance fund balance, balances are mainly attributed to the district coordinating control and use, gaps are generally required level government and the governments at the corresponding levels to fill. If the insured in different district co-ordination between the transfers of pension insurance relationship, it will affect the district coordinating old-age insurance fund collection, management, and use. Therefore, most of the district coordinating does not support pension insurance relationship of barrier free transfer, but to add some conditions, in order to reduce the possibility of loss (Zhang, X. 2009. "The Analysis of Supply and Demand Adaptation of Migrant Workers' Endowment Insurance Relationship Transfer and Continuation." Master dissertation, Southwestern University of Finance and Economics. P. 28).

2. The "lemon market", namely the defective market (Akerlof, the 2001 Nobel Prize winner in economics). It refers to when the information is incomplete, even if some people want to buy, some people want to sell, but the transaction cannot happen, which is the market failure.

\section{References}

Chen, J. J. 2012. "Exploration of the Causes of Migrant Workers 'Surrender Boom', Thinking of Migrant Workers Pension Insurance System.” The Financial Economy Monthly (Changsha) 12:12.
Gu, Y. T. 2011. "Migrant Workers Endowment Insurance Issues.” North China Finance Monthly (Tianjin) 7:81.

Huang, C. 2012. "The New Generation of Migrant Workers in the Construction of the Social Security System of Interest Analysis.” Harbin Municipal Party School Journal (Harbin) 1:53.

Mao, Y. 2013. "Migrant Workers Endowment Insurance Issues and Solutions to Explore.” Economic Research Ginseng Insurance Weekly (Beijing) 11:53.

Xu, X. P. 2014. "Under the Perspective of Social Security, the Pension Insurance of Migrant Workers.” Journal of Shanxi Agricultural University (Social Science Edition) Monthly (Jinzhong) 10(3):257.

Yuan, Y. 2010. "The Chinese Rural Migrant Workers Rights and Interests of Endowment Insurance Deficiency and Perfection.” Golden Card Project (Economic and Judicial) Monthly (Guangzhou) 8:187.

Zhang, H. J. and C. Y. Dong. 2014. "To Strengthen the Social Security Policy Implementation of Migrant Workers Research-Based on the Perspective of the Interests of the Game.” Social Security Research (Wuhan) 2:97-98.

Zhang, N. 2013. "The Plight of Migrant Workers Endowment Insurance and Its Influencing Factors.” Labor Security World Monthly (Changchun) 2:32.

Zhang, W. B. 2010. "Migrant Workers Endowment Insurance System to Build the Target and Train of Thought." Urban Problems Monthly (Beijing) 4:57-58.

Zhu, S. K. and Y. Chen. 2012. "The Migrant Workers Endowment Insurance Difficulties and Causes-Based on a Social Justice Perspective.” Journal of Wenzhou Vocational and Technical College and (Wenzhou) Quarterly 11(1):48.

\section{Bio}

Huofa Luo, master, lecturer, Jiaxing University, Zhejiang, China; research field: social problems and governance in China. 